\begin{tabular}{|c|c|c|}
\hline & Our & $\begin{array}{l}\text { ISSN: 1991-2951 (Print) } \\
\text { ISSN: 2091-2781 (Online) }\end{array}$ \\
\hline $\begin{array}{l}\text { Nature Conservation \& } \\
\text { Health Care Council } \\
\text { Blictingogar. Nopacal }\end{array}$ & Journal homepage: http://nepjol.info/index.php/ON & (c) (1) (5) \\
\hline
\end{tabular}

\title{
Effect of environmental regulated water temperature variations on survival, growth performance and haematology of African catfish, Clarias gariepinus
}

\author{
Johnny O. Ogunji ${ }^{1,2^{*}}$ and Jude Awoke ${ }^{1}$ \\ ${ }^{1}$ Department of Fisheries and Aquaculture, Ebonyi State University, Abakaliki, Nigeria \\ ${ }^{2}$ Faculty of Agriculture, Federal University Ndufu Alike Ikwo Ebonyi State, Nigeria \\ *E-mail: ogunjijo@yahoo.com
}

\begin{abstract}
A 56 day study was carried out to evaluate effect of temperature changes on survival, growth performance and haematology of Clarias gariepinus fingerlings fed housefly maggot meal (magmeal) diet. Ninety (90) Clarias gariepinus fingerlings, (initial mean weight $4.33 \pm 0.03 \mathrm{~g}$ ) were subjected to different environmental regulated temperature conditions in three locations (laboratory, outdoor, greenhouse). The observed average temperature was $26.53 \pm 0.01^{\circ} \mathrm{C}, 26.06 \pm 0.01^{\circ} \mathrm{C}$ and $31.52 \pm 0.00^{\circ} \mathrm{C}$ for laboratory, outdoor, greenhouse, respectively. Ten fingerlings stocked per experimental tank were fed in triplicates at 5\% body weight in two portions per day. It was observed that different water temperatures affected fish growth. All experimental fish in the greenhouse died after 8 days of exposure. This happened around $14.00 \mathrm{hrs}$ when water temperature reached $40^{\circ} \mathrm{C}$. There was no significant difference $(\mathrm{P}<0.5)$ in final weight, weight gain, food conversion ratio and standard growth rate among the fish reared in the laboratory $\left(26.53^{\circ} \mathrm{C}\right)$ and outside tanks $\left(26.06^{\circ} \mathrm{C}\right)$, respectively. The initial carcass crude protein $(\mathrm{Cp})$ value was $58.97 \%$. At the end of the experiment fish reared in the laboratory had a crude protein value of $63.97 \pm 0.06 \% \mathrm{Cp}$ and those reared outdoor $\left(26.06^{\circ} \mathrm{C}\right)$ had $71.28 \pm 0.00 \% \mathrm{Cp}$. No significant difference in values of packed cell volume; white blood cell; haemoglobin and mean corpuscular haemoglobin concentration was found between fish reared in laboratory $\left(26.53^{\circ} \mathrm{C}\right)$ and outside $\left(26.06^{\circ} \mathrm{C}\right)$. However, the red blood cell $(\mathrm{RBC})$; mean corpuscular haemoglobin and mean corpuscular volume showed significant difference $(\mathrm{P}>0.05)$. The result confirms that Clarias gariepinus fingerlings reared at a mean temperature of $26^{\circ} \mathrm{C}$ (within the recorded optimal temperature range for good growth) performed well. Clarias gariepinus fingerlings are not able to survive when water temperature reaches to $40^{\circ} \mathrm{C}$.
\end{abstract}

Key words: Fish growth, Climate change, Temperature, Blood characteristics

DOI: http://dx.doi.org/10.3126/on.v15i1-2.18791

Manuscript details: Received: 26.01.2017 / Accepted: 13.07.2017

Citation: Ogunji, J.O. and J. Awoke 2017. Effect of environmental regulated water temperature variations on survival, growth performance and haematology of African catfish, Clarias gariepinus. Our Nature 15(1-2): 26-33. DOI: http://dx.doi.org/10.3126/on.v15i1-2.18791

Copyright: @ Ogunji and Awake, 2017. Creative Commons Attribution - Non Commercial 4.0 International License.

\section{Introduction}

Climate change refers to the variation in the earth's global climate or in regional climate over time. It describes changes in the variability or average state of the atmosphere over time scales ranging from decades to millions of years (Emmanuel, 2005). Ongoing climate change is predicted to affect individual organisms during 
all life stages, thereby affecting populations of a species, communities and the functioning of ecosystems (Pörtner and Peck, 2010). Current rates of climate change are unprecedented, and biological responses to these changes have also been rapid at the levels of ecosystems, communities, and species (Heino et al., 2009).

The effects of climate change according to Pörtner and Peck (2010) can be direct, through changing water temperatures and associated phenologies, the lengths and frequency of hypoxia events, through ongoing ocean acidification trends or through shifts in hydrodynamics and in sea level. Okorafor (2014) posits that change in climate affects aquatic species at various trophic levels, the physical and chemical environment that make up their habitat and the processes that act on and within freshwater ecosystems. Climate change directly affects a range of physical, chemical and biological processes in the aquatic systems. The extent and magnitude of the ecological consequences of climate change in freshwater ecosystems depends largely on temperature and alterations in water chemistry such as nutrient levels, dissolved organic carbon (DOC), dissolved oxygen (DO) and particulate organic matter (POM).

In fish as well as other such organisms, the body physiological and biochemical processes functions according to the dictates of prevailing water temperature (Holt and Jorgenson, 2015). Elevated temperatures positively alter the breathing rates, feed consumption, enzyme activities, oxygen consumption and feed metabolism thereby affecting growth (Magawata and Ipinjolu, 2014). The growth rate will determine how fast maturity size is attained, the fecundity, recruitment into the exploitable phase of the population and ultimately influence increase in population size (Koeypudsa and Jongjareanjai, 2010).

Fish exist closely with their surroundings. Hence, it is always helpless to physical or chemical fluctuations which possibly will in turn be manifested in the fish haematological characteristics (Wilson and Taylor, 1993). The study of fish blood has advanced rapidly in fish farming due to its relevance in checking the wellbeing of fishes (Hrubec et al., 2000). Haematocrit (PCV), haemoglobin $(\mathrm{Hb})$ concentration and red blood cell count (RBC) differ with the type of food the fish eats, temperature, time of the year and strain (Dienye and Olumuji, 2014).
It has been observed (Cheung et al., 2010), that biological, ecological and physical consequences of global warming on water bodies are becoming glaring. Fishes that attract high market values now migrates pole wards into deeper seas hastily thereby moving away from tropical seas. Holt and Jorgenson (2015) noted that poikilothermic organisms have been subjected to huge and often frequent alterations in the temperature of their habitats. The ultimate effect of temperature fluctuations may be felt on growth impairment, maturation, reproductive capacity and overall population size of fish stocks. This no doubt may present an economic issue for any country.

An alteration in the environmental temperature of a habitat may change the behaviour and haematological processes of fish (Mali and Chavan, 2014). Temperature therefore, is an indispensable and variable ecological issue affecting all living actions which brings about direct outstanding variations on haematological characteristics of organisms that live in water. It is equally acknowledged that temperature seriously affects reproduction, effective growth, immunological efficiency and activities of enzyme in fish (Tanck et al., 2000).

Considering the serous effect of climate change on fish and fish culture, this study is intended to provide information on the effect of slight temperature changes on Clarias gariepinus. It will illuminate the sensitivity of Clarias gariepinus to temperature alterations in the light of climate change. The research is undertaken to determine the effect of environmental regulated temperature variations on the haematology of Clarias gariepinus fingerlings fed housefly maggot diet.

\section{Materials and methods}

\section{Preparation of experimental diets}

One experimental diet, with protein content of $41.97 \%$ dry matter, was prepared. Housefly maggot meal $(50 \%)$ was used as the major dietary protein source in the diet. Other ingredients that were used in the formulation include soya bean meal (34\%), maize (14.5\%), fish oil $(0.25 \%)$, Goundnut oil $(0.25 \%)$ and vitamin premix $(1 \%)$. The diets were pelleted using pelleting machine and the pellets were sundried. Magmeal was produced according to the description of Ogunji et al. (2008).

Vitamin premix supplying for each kilogram of food at $5 \mathrm{~kg} /$ tone had following 
addition: 20,000 i.u, $30 \mathrm{mg}$ Manganese, $4 \mathrm{mg}$ Copper, $40 \mathrm{mg}$ Zinc, $0.2 \mathrm{mg}$ Selenium, $100 \mathrm{mg}$ Lysine, $100 \mathrm{mg}$ Methionine, $100 \mathrm{mg}$ Antioxidant, Vitamin A, 2000 i.u, Vit. D3, $200 \mathrm{mg}$ Vit E, $8 \mathrm{mg}$ Vit K3, $20 \mathrm{mg}$ Vit B1, $30 \mathrm{mg}$ Vit B2, $12 \mathrm{mg}$ Vit B6, $50 \mathrm{mg}$ Pantothenic acid, 0.8 $\mathrm{mg}$ Biotin, $2.0 \mathrm{mg}$ Cobalt, $40 \mathrm{mg}$ Iron, $5.0 \mathrm{mg}$ lodine, $150 \mathrm{mg}$ Niacin, $0.05 \mathrm{mg}$ Vit B12, $4.0 \mathrm{mg}$ Folic acid, $500 \mathrm{mg}$ Vit C, $600 \mathrm{mg}$ Choline chloride, $200 \mathrm{mg}$ Inositol, $200 \mathrm{mg}$ Betaine.

\section{Experimental fish}

A total of ninety (90) Clarias gariepinus fingerlings (initial average weight $4.33 \pm 0.03 \mathrm{~g}$ ) were acclimatized for seven days. They were weighed and distributed among nine experimental tanks at a rate of ten fish per aquarium tank with 20 litres of water. Test diets were randomly assigned using completely randomized design to triplicate tanks located in laboratory, outdoor and greenhouse. The fish were fed a restricted ration of 5\% body weight per day in two portions (by $9.00 \mathrm{hrs}$ and $15.00 \mathrm{hrs)}$ ) for 56 days in static water. Quantity of feed was adjusted forth nightly after batch-weighing of experimental fish. The aquaria were cleaned and water partly replaced by siphoning every three days to avoid fouling. Water temperature, dissolved oxygen, $\mathrm{pH}$, nitrate, nitrite and ammonia were checked daily using mercury in glass bulb thermometer (Fresh Innovative Multitech, NIFFRI and water testing kit (Nice Chemicals India) respectively in the six treatment tanks. Water temperature in the experimental tanks was measured three times daily in the morning (6.00 hrs), afternoon (14.00 hrs) and evening (18.00 hrs).

\section{Biochemical and haematological analysis}

Blood samples were collected at the commencement and at the end of the experiment from the caudal vein into an EDTA litium tubes. The blood was analyzed to determine the packed cell value (PCV) with microhaematocrit using heparnized capillary tube $(25 \mathrm{~mm})$. Red blood cell (RBC) and white blood cell (WBC) counts were determined as described by Blaxhal and Diasley (1973). Hemoglobin (Hb) concentration was determined by the methods described by Wedemeyer and Yasutake (1977). Other haematological indices like mean cell haemoglobin $(\mathrm{MCH})$, mean cell volume (MCV) and mean cell haemoglobin concentration (MCHC) were determined using the formula put forward by Dacie and Lewis (2001) thus:
$\mathrm{MCH}(\mathrm{pg})=\left[\mathrm{Hb}\left(\mathrm{g} \mathrm{dl}^{-1}\right) \times 10\right] / \mathrm{RBC}\left(10^{6} \mu \mathrm{l}^{-1}\right)$

$\operatorname{MCV}(\mathrm{fl})=\operatorname{Hct} / \operatorname{RBC}\left(10^{6} \mu 1^{-1}\right)$

$\operatorname{MCHC}\left(\mathrm{g} \mathrm{l}^{-1}\right)=\left(\mathrm{Hb}\left(\mathrm{g} \mathrm{dl}^{-1}\right) \times 10\right] / H c t \times 100$

Protein $(\mathrm{N} x$ 6.25) was determined by the Kjeltec System (Tecator) and crude fat by Soxtec System HT (Tecator) using petroleum ether. Ash was determined by burning in a muffle furnace at $550^{\circ} \mathrm{C}$ for $10 \mathrm{hrs}$. Gross energy was calculated using the following factors: crude protein $=23.9 \mathrm{~kJ} / \mathrm{g}$, crude lipids $=$ $39.8 \mathrm{~kJ} / \mathrm{g}$ and NFE $=17.6 \mathrm{~kJ} / \mathrm{g}$ (Schulz et al., 2005).

\section{Statistical and growth analysis}

At the end of the experiment, all the fish was weighed and data obtained from triplicate tanks were used to calculate weight gains, specific growth rate (SGR), feed conversion ratio (FCR) and percentage body weight.

Weight gain = final weight - initial weight,

$\mathrm{SGR}=\left(\mathrm{LnW}_{2}-\mathrm{LnW}_{1}\right) /\left(\mathrm{T}_{2}-\mathrm{T}_{1}\right) 100$

Where, $\mathrm{W}_{1}$ and $\mathrm{W}_{2}=$ initial and final weight of fish and $T_{1}$ and $T_{2}=$ time in days.

$$
\mathrm{FCR}=\frac{\text { Feed fed }}{\text { live weight gain }}
$$

Protein efficiency ratio $(\mathrm{PER})=$ live weight gain (g) / protein fed $(\mathrm{g})$

Where,

$\mathrm{F} 1=$ number of fish at the end of experiment, F2 = number of fish at the beginning of experiment.

All growth and heamatological data were subjected to one way analysis of variance (ANOVA). The significance of difference between means was determined by Duncan's Multiple Range test $(\mathrm{p}<0.05)$ using SPSS for windows (version 21). Values were expressed as means \pm SE.

\section{Results}

Fish mortality was observed in the greenhouse treatment when water temperature reached $40^{\circ} \mathrm{C}$. All the experimental fish died on the $8^{\text {th }}$ day of experimental exposure. Therefore there was no fish in this particular treatment for subsequent and final sample collection at the end of the experiment. Nevertheless, there was no significant mortality in the remaining treatments.

The mean value and standard error (SE) of all water quality parameters for each treatment group are summarized (Table 1). Temperature values differed significantly $(P<0.05)$ in the 
three locations but did not differ significantly in the varying water levels (volumes). Highest temperature value was recorded in greenhouse tanks (MMG20).

Table 1. Water quality parameters in experimental tanks.

\begin{tabular}{lccr}
\hline Parameter & MML20 $^{1}$ & MMO20 $^{2}$ & MMG20 $^{3}$ \\
\hline Temp $\left({ }^{\circ} \mathrm{C}\right)$ & $26.53 \pm 0.01^{\mathrm{b}}$ & $26.06 \pm 0.01^{\mathrm{a}}$ & $31.52 \pm 0.00^{\mathrm{c}}$ \\
\hline $\mathrm{DO}(\mathrm{mg} / \mathrm{l})$ & $5.17 \pm 0.14^{\mathrm{a}}$ & $5.33 \pm 0.17^{\mathrm{a}}$ & $4.65 \pm 0.57^{\mathrm{a}}$ \\
\hline $\mathrm{pH}$ & $6.71 \pm 0.12^{\mathrm{a}}$ & $6.72 \pm 0.12^{\mathrm{a}}$ & $7.16 \pm 0.17^{\mathrm{a}}$ \\
\hline Nitrate $(\mathrm{mg} / \mathrm{l})$ & $1.96 \pm 0.05^{\mathrm{a}}$ & $1.96 \pm 0.05^{\mathrm{a}}$ & $1.62 \pm 1.11^{\mathrm{a}}$ \\
\hline Nitrite $(\mathrm{mg} / \mathrm{l})$ & $0.02 \pm 0.01^{\mathrm{a}}$ & $0.02 \pm 0.01^{\mathrm{a}}$ & $0.00 \pm 0.00^{\mathrm{a}}$ \\
\hline $\begin{array}{l}\text { Ammonia } \\
(\mathrm{mg} / \mathrm{l})\end{array}$ & $2.56 \pm 0.72^{\mathrm{a}}$ & $2.37 \pm 0.14^{\mathrm{a}}$ & $3.00 \pm 0.00^{\mathrm{a}}$ \\
\hline${ }^{1} \mathrm{MML20}$ (Laboratory & Tank 20L & $\begin{array}{r}\text { Treatment), } \\
{ }^{2} \mathrm{MMO} 20 \text { (Outdoor Tank 20L Treatment), }\end{array}{ }^{3}$ MMG 20 \\
(Greenhouse Tank 20L Treatment)
\end{tabular}

Dissolved oxygen, $\mathrm{pH}$, nitrate, nitrite and ammonia were observed not to be significantly different $(\mathrm{P}<0.05)$ in all the treatment groups.

Proximate nutrient compositions of feed stuffs and experimental diet used in this trial are presented (Tables 2-3). The dietary crude protein composition was $41.97 \%$ while dietary crude fat was $3.56 \%$.

Table 2. Proximate composition of maggot meal and soybean meal used for diet formulation.

\begin{tabular}{lcc}
$\begin{array}{l}\text { Proximate } \\
\text { components (\%) }\end{array}$ & $\begin{array}{c}\text { Maggot meal } \\
\text { (MGM) }\end{array}$ & $\begin{array}{c}\text { Soybean meal } \\
\text { (SBM) }\end{array}$ \\
\hline Crude protein & 44.87 & 43.78 \\
Crude fat & 7.38 & 3.67 \\
Crude fibre & 6.88 & 6.48 \\
Crude Ash & 7.95 & 5.96 \\
Moisture content & 7.35 & 5.63 \\
NFE & 25.57 & 34.48 \\
\hline
\end{tabular}

Table 3. Proximate composition (\%) of the experimenttal diet.

\begin{tabular}{ll}
\hline Parameter & Diet \\
\hline Dry Matter & 91.95 \\
Crude protein & 41.97 \\
Crude fat & 3.56 \\
Crude fibre & 2.54 \\
Crude Ash & 7.69 \\
Moisture content & 8.05 \\
NFE & 36.19 \\
\hline
\end{tabular}

The Food Conversion Ratio (FCR), Standard Growth Rate (SGR) and other growth performance parameters of Clarias gariepinus fingerlings fed experimental diet are presented (Table 4). At the ending of the experimentation, the fingerlings increased from an initial mean body weight of $4.33 \mathrm{~g}$ to represent a final mean body weight $13.10 \mathrm{~g}$. Highest mean weight gain
MWG and SGR were observed in Clarias gariepinus reared in laboratory (MML20), followed by fish in outdoor (MMO20). However, mean weight gain was highest in treatment laboratory (MML20). PER shows no significant difference between laboratory (MML20) and outdoor (MMO20).

Table 4. Growth performance of Clarias gariepinus fingerlings fed experimental diet*

\begin{tabular}{lcr}
\hline Parameters & MML20 & MMO20 \\
\hline Initial Weight $(\mathrm{g})$ & $4.34 \pm 0.26^{\mathrm{a}}$ & $4.33 \pm 0.03^{\mathrm{a}}$ \\
Final Weight $(\mathrm{g})$ & $13.10 \pm 1.47^{\mathrm{c}}$ & $11.17 \pm 1.93^{\mathrm{c}}$ \\
Weight Gain (g) & $8.76 \pm 1.21^{\mathrm{c}}$ & $6.83 \pm 1.94^{\mathrm{c}}$ \\
$\mathrm{FCR}^{1}$ & $1.61 \pm 0.10^{\mathrm{b}}$ & $1.67 \pm 0.73^{\mathrm{b}}$ \\
SGR $^{2}$ & $1.96 \pm 0.10^{\mathrm{c}}$ & $1.64 \pm 0.30^{\mathrm{c}}$ \\
PER $^{3}$ & $0.21 \pm 0.03^{\mathrm{c}}$ & $0.16 \pm 0.05^{\mathrm{c}}$ \\
\hline
\end{tabular}

*All values are mean of triplicate feeding groups and values in the same row with different superscripts are significantly different $(\mathrm{P}<0.05)$; ${ }^{1}$ Food conversion ratio $=$ food fed $(\mathrm{g}) /$ live weight gain $(\mathrm{g}) ;{ }^{2}$ Specific growth rate $(\% / \mathrm{d})=(\operatorname{InW} 2-\mathrm{InW} 1 / \mathrm{T} 2-\mathrm{T} 1) \times 100$; ${ }^{3}$ Protein efficiency ratio $=$ live weight gain $(\mathrm{g}) /$ protein fed (g),

The body proximate composition of Clarias gariepinus fed experimental diet is presented (Table 5). At all phases of the experiment, it was noticed that the dietary protein increased in all the treatments when compared with the initial status. However, fish in outdoor tank (MMO20) accumulated more body protein and was significantly different $(\mathrm{P}<$ 0.05 ) from other treatments. Crude ash, crude fibre, crude fat and moisture were significantly decreased $(\mathrm{P}<0.05)$ from the initial status. Values of greenhouse tanks (MMG20) are not shown because the experimental fish in the treatment died before the end of experiment.

Table 5. Initial and final carcass composition of $C$. gariepinus fingerlings fed experimental diet $(\%)^{*}$

\begin{tabular}{lccc}
\hline $\begin{array}{l}\text { Compo- } \\
\text { nents (\%) }\end{array}$ & $\begin{array}{c}\text { Initial } \\
\text { status }\end{array}$ & MML20 & MMO20 \\
\hline $\begin{array}{l}\text { Crude } \\
\text { protein }\end{array}$ & $58.97 \pm 0.00^{\mathrm{a}}$ & $63.97 \pm 0.06^{\mathrm{b}}$ & $71.28 \pm 0.00^{\mathrm{e}}$ \\
\hline Crude fat & $8.25 \pm 0.01^{\mathrm{d}}$ & $5.87 \pm 0.06^{\mathrm{a}}$ & $6.89 \pm 0.00^{\mathrm{c}}$ \\
\hline Crude ash & $12.49 \pm 0.01^{\mathrm{d}}$ & $7.58 \pm 0.06^{\mathrm{a}}$ & $9.07 \pm 0.00^{\mathrm{b}}$ \\
\hline Moisture & $8.4 \pm 0.01^{\mathrm{e}}$ & $6.68 \pm 0.06^{\mathrm{c}}$ & $5.25 \pm 0.00^{\mathrm{a}}$ \\
\hline NFE $^{\mathrm{a}}$ & $11.71 \pm 0.01^{\mathrm{c}}$ & $15.90 \pm 0.14^{\mathrm{d}}$ & $7.51 \pm 0.00^{\mathrm{a}}$
\end{tabular}

*All values are mean of triplicate feeding groups and values in the same row with different superscripts are significantly different $(\mathrm{P}<0.05) ;{ }^{1}$ Nitrogen free extract + fibre, $(\mathrm{NFE})=100-(\%$ protein $+\%$ fat $+\%$ ash $)$.

Haematological indices of Clarias gariepinus fingerlings fed experimental diet and exposed to varying temperatures are presented 
(Table 6). The packed cell volume results showed that the initial PCV count was significantly decreased $(\mathrm{P}<0.05)$ in all treatments. The results obtained for haemoglobin $\mathrm{Hb}$ showed that the initial status was significantly different in all the treatments. However, other treatments were significantly decreased $(\mathrm{P}<0.05)$ from the initial status. With regards to $\mathrm{WBC}$, all the treatment groups did not differ significantly. RBC values in all treatment groups significantly decreased $(\mathrm{P}<0.05)$ from the initial status.

Table 6. Haematological Indices of Clarias gariepinus fingerlings fed experimental diet and exposed to varying temperatures*

\begin{tabular}{lccc}
\hline Parameters & Initial & MML20 & MMO20 \\
\hline PCV (\%) & 26.00 & 20.00 & 20.00 \\
& $\pm 0.58^{\mathrm{b}}$ & $\pm 1.54^{\mathrm{a}}$ & $\pm 0.58^{\mathrm{a}}$ \\
\hline $\mathrm{Hb}(\mathrm{g} / 100 \mathrm{ml})$ & 8.70 & 6.60 & 6.60 \\
& $\pm 0.58^{\mathrm{a}}$ & $\pm 0.23^{\mathrm{a}}$ & $\pm 0.17^{\mathrm{a}}$ \\
\hline $\mathrm{WBC}\left(10^{3}\right) \mathrm{mm}^{-3}$ & 78.00 & 57.00 & 58.00 \\
& $\pm 57.74^{\mathrm{ab}}$ & $\pm 230.94^{\mathrm{a}}$ & $\pm 173.20^{\mathrm{a}}$ \\
\hline $\mathrm{RBC}\left(10^{3}\right) \mathrm{mm}^{-3}$ & 6.40 & 3.80 & 6.90 \\
& $\pm 0.12^{\mathrm{a}}$ & $\pm 0.17^{\mathrm{a}}$ & $\pm 0.14^{\mathrm{a}}$ \\
\hline $\mathrm{MCHC}(\%)$ & 30.56 & 33.09 & 33.01 \\
& $\pm 3.13^{\mathrm{a}}$ & $\pm 0.76^{\mathrm{a}}$ & $\pm 0.09^{\mathrm{a}}$ \\
\hline $\mathrm{MCH}(\mathrm{pg})$ & 7.36 & 17.93 & 9.58 \\
& $\pm 0.18^{\mathrm{a}}$ & $\pm 0.71^{\mathrm{c}}$ & $\pm 0.41^{\mathrm{b}}$ \\
\hline $\mathrm{MCV}(\mathrm{fl})$ & 40.62 & 52.57 & 29.00 \\
& $\pm 0.17^{\mathrm{b}}$ & $\pm 0.65^{\mathrm{c}}$ & $\pm 1.34^{\mathrm{a}}$ \\
\hline
\end{tabular}

*All values are mean of triplicate feeding groups and values in the same row with different superscripts are significantly different $(\mathrm{P}<0.05) \mathrm{PCV}$, Packed cell volume; WBC, white blood cell; $\mathrm{RBC}$, red blood cell; $\mathrm{Hb}$, haemoglobin; MCHC, mean corpuscular haemoglobin concentration; $\mathrm{MCH}$, mean corpuscular haemoglobin; MCV, mean corpuscular volume.

\section{Discussion}

Temperature of water based ecosystem is critical for guaranteeing the existence, production and adequate metabolic activities in fish. Inability to get used to temperature variations may result in fish mortality (Singh et al., 2013). In this experiment all the experimental fish in the greenhouse died after 8 days of exposure. This happened around $1400 \mathrm{hrs}$ when the temperature in the water reached $40^{\circ} \mathrm{C}$. According to Cnaani (2006) temperature beyond optimum limits negatively impacts the wellbeing of fish as a result of metabolic strain which ultimately hinders immunity levels, reproductive capacity and growth. The normal range of temperature tolerance in the tropics to which fish are adapted is $22-35^{\circ} \mathrm{C}$ (Howerton, 2001). This concurs with the work of Adeyemo et al. (2003) who found out that during temperature extremes Clarias gariepinus fails to adapt and will be unable to respond physiologically. This results in mortality which is caused by changes in the metabolic pathways and collapse in osmoregulatory functions.

One of the most critical abiotic factors impacting oxygen levels in water based ecosystems is the temperature of water. There is an inverse relationship between temperature increase and oxygen level. The solubility of oxygen decreases as water temperature increases (NOAA, 2008). The result of the present study shows that mean temperature values differed significantly in all the treatment groups. MML20 and $\mathrm{MMO} 20$ recorded mean temperatures of $26.53 \pm 0.01^{\circ} \mathrm{C}$ and $26.06 \pm 0.01^{\circ} \mathrm{C}$ respectively. Kausar and Salim (2006) established that the most favourable temperature for superlative growth of European catfish silirus glanis was between $25^{\circ} \mathrm{C}$ and $28^{\circ} \mathrm{C}$. Most excellent outcomes were recorded at $27^{\circ} \mathrm{C}$.

Greenhouse treatment recorded the highest value $31.52 \pm 0.00$ (Table 1 ). This can be attributed to the realities that for the period of sunlight, all the energy from the sunrays are taken up by greenhouse covering. Some of the energy is reflected outwards while a larger percentage is soaked up and conveyed within the greenhouse rooftops and walls (Ani-sabwa et al., 2014). A huge quantity of this conveyed energy is taken up by water thereby helping to raise water temperature within the greenhouse. Once water is extremely warmed, vapour, oxygen and a large amount of energy is emitted into the atmosphere. The water is then highly concentrated with carbon dioxide thereby extremely increasing its acid content.

Dissolved oxygen and $\mathrm{pH}$ values for the treatment groups were within the range suitable for rearing fish (Dienye and Olumuji, 2014). Research has proved that fish feeding, growth and reproduction is enhanced at DO level of $5 \mathrm{mg} / \mathrm{l}$ and above. Fish will feed poorly and starve at low concentration of DO that is below 3 mg/l (NAERLS, 1996). NAERLS (1996) further posits that $\mathrm{pH}$ is a key chemical factor to contemplate because it influences metabolic activities and other body processes of aquacultural animals. An acceptable $\mathrm{pH}$ range (6.88.7) ought to be sustained for satisfactory growth efficiency and production capacity.

Fish growth performance was good as evidenced by an upsurge in body mass and growth of the experimental fishes. By the end of 
the experimentation, the fishes developed from an original body mass of $4.33 \mathrm{~g}$ to a finishing average body weight of $13.10 \mathrm{~g}$. Growth performance of Clarias gariepinus was highest in laboratory treatment tanks (MML 20) having final mean weight of $13.10 \pm 1.47 \mathrm{~g}$ whereas outdoor treatment tank 20 (MMO 20) was 11.17 $\pm 1.93 \mathrm{~g}$ (Table 4 ).

Feed conversion ratio (FCR) is a significant indicator of the excellence of fish feed. A lower FCR indicate improved use of the fish feed (Mungo-Bundi et al., 2013). In this experiment, FCR presented no significant difference in all the treatments. However, the best FCR $(1.61 \pm$ $0.73)$ was observed in fish reared in laboratory tank (MML20) which had mean temperature of $26.53 \pm 0.01^{\circ} \mathrm{C}$. This was followed by $(1.67 \pm$ $0.10)$ for fish reared in outdoor tank (MMO20) with mean temperature of $26.06 \pm 0.01^{\circ} \mathrm{C}$. These outcomes are in agreement with the results of Kausar and Salim (2006). They reported that Labeo rohita, fingerlings reared at a temperature range of $24-26^{\circ} \mathrm{C}$ registered improvement in FCR. However, FCR values of less than 1 have been documented even though $1.2-1.5$ is the normal range for fish reared with properly compounded diet (Ogunji et al., 2008). The low FCR of $1.61-1.67$ exhibited by fish in all the treatment groups is an indicator that the fish utilized the feed well.

The proximate composition of carcass in this study indicated that all experimental groups recorded higher levels of crude protein than the initial value. This shows that the magmeal experimental diet was well accepted and utilised by Clarias gariepinus. Several authors have reported same previously (Ogunji et al., 2007; Idowu and Afolayan, 2013).

Study of haematological parameters is important for the diagnoses of health condition of fish under different stress situations (Adhikari et al., 2004). The constituents of blood are very susceptible to temperature and if there is a variation physiologically, it will be manifested in the standards of some blood characteristics (Ramesh et al., 2009). This might influence the normal body process of procreation and overall amount of fish stock. Variation in the blood parameters of catfish as result of stresses brought about by changes in the temperature of water have been investigated by several persons (Adhikari et al., 2004; Mali and Chavan, 2014).
Every single one of the blood characteristics determined in this experiment fell within the authorized body limits documented for Clarias gariepinus. Haematocrit (PCV) limits 20 - 26\% recorded in this investigation are within the limits of $20-50 \%$ documented by Dienye and Olumuji (2014). However, values above 50\% are rarely reported (Etim et al., 1999). A decrease in PCV values were observed in all treatments of this study, respect to initial status. A decrease in the amount of the PCV in the blood normally is an indication that there is a shortfall in the expected level of red blood cells. Causes of low haematocrit include anemia, trauma, and damage of red blood cells or decreased production of red blood cells (Oyawoye and Ogunkunle, 1998). A rise in temperature brings about a great reduction in the ability of blood to carry oxygen and this causes an upsurge in red blood cells in the blood (Holt and Jorgerson, 2015).

The haemoglobin result showed a decrease from the initial value. The haemoglobin $(\mathrm{Hb})$ range $5.30-8.70 \mathrm{~g} / 100 \mathrm{ml}$ (Table 6) recorded in this study is similar to $8.7 \mathrm{~g} / 100 \mathrm{ml}$ for Clarias gariepinus as reported by Sowunmi, (2003). These records were as well more than 4.46 $\mathrm{g} / 100 \mathrm{ml}$ as reported by Fagbenro et al. (2000) for Heterotis niloticus. In this study however, the decrease in haemoglobin from the initial value does not constitute any problem since it is within the required standards.

Also, a decrease in the erythrocytes (RBC) was detected in the treatment groups except outdoor tank. RBC for MMO20 (outdoor tank) was higher than the initial value. It is acknowledged that a low quality and small amounts of red blood cells as well as low level of haemoglobin leads to a decline in the availability of oxygen in the body. Apart from transportation of oxygen, red blood cells perform other important functions in the body and inadequate amounts and quality of red blood cells would have a chain of consequences on metabolic activities other than just the provision of oxygen for respiration (Gross et al., 1996).

\section{Conclusion}

Findings from this study suggest that temperature changes affected the growth and body composition of Clarias gariepinus. Fish reared in MML20 (laboratory tank) did better than other treatments. Haematological characteristics of all treatment groups responded negatively to different temperature exposures. This is evidenc- 
ed by the mortality witnessed in the greenhouse treatment and low blood characteristics values obtained from the experiment.

Nevertheless, the experimental fish showed good results in growth performance and body composition. The mean weight gain MWG, FCR, SGR and PER showed significant difference between the treatment groups. However, fish reared under laboratory ambient temperature conditions performed better than others.

Water temperature is known to influence the haematological parameters of fish. When blood parameters are affected negatively, it further impinges on growth presentation and overall wellbeing of fishes. The result of this investigation demonstrates that $25-28^{\circ} \mathrm{C}$ is a suitable temperature range that is appropriate for growth and wellbeing of Clarias gariepinus. However temperature exceeding $40^{\circ} \mathrm{C}$ can be very lethal to the fish. Finally, more detailed research is needed to authenticate this result.

\section{References}

Adeyemo, O.K., S.A. Agbede, A.O. Olaniyan and O.A.Shoaga 2003. The haematological response of Clarias Gariepinus to changes in acclimation temperature. African Journal of Biomedical Research 6: 105-108.

Adhikari, S.,B. Sarkar, A. Chatterjee, C.T. Mahapatra and S. Ayyappan 2004. Effects of cypermethrin and carbofuran on certain hematological parameters and prediction of their recovery in a freshwater teleost; Labeo rohita (Hamilton). Ecotoxicological Environmental Safety 58: 220226.

Ani-Sabwa, J., C.M. Mlewa and J. Njiru 2014. Effects of greenhouse and stocking density on growth and survival of African catfish (Clarias gariepinus Burchell 1822) fry reared in high altitude Kenya regions. International Journal of Science and Research (Online): 2319-7064.

Cheung, W.W.L., V.W.Y. Lam, J. L. Sarmiento, K. Kearney, R. Watson, D. Zeller and D. Pauly 2010. Large-scale redistribution of maximum fisheries catch potential in the global ocean under climate change. Global Change Biology 16: $24-35$.

Cnaani, A. 2006. Genetic perspective on stress and disease resistance in Aquaculture. Isreali Journal of Aquaculture Bamidgeh 58: 375-383.

Dacie, J.V. and S.M. Lewis 2001. Practical haematology ( $9^{\text {th }}$ ed). Churchill Livingstone, London. $633 \mathrm{p}$.

Dienye, H.E. and O.K. Olumuji 2014. Growth performance and haematological responses of African mud catfish Clarias gariepinus fed dietary levels of Moringa oleifera leaf meal. Net Journal of Agricultural Science 2(2): 79-88.

Emmanuel, K.A. 2005. Increasing destructiveness of tropical cyclones over the past 30 years. Nature 436: 686-688.

Etim, L., P.E. Lebo and R.P. King 1999. The dynamics of an exploited population of Siluroid Catfish (Schilbe Intermedius Ruppell, 1832) in the Cross river. Nigeria Fishery Research 40: 295-307.

Fagbenro, O., C.O. Adedire, E.O. Ayotunde and E.O. Faminu 2000. Haematological profile, food consumption and enzyme assay in the gut of the African bony-tongue fish Heterotis (clupisudis) niloticus (Cuvier 1829) (Osteoglossidae). Tropical Zoology 13: 1-9.

Gross, R., M. Gliwitzki, P. Gross and F. Klaus 1996. Food and nutrition Bulletin 17(1). United Nations University Press.

Heino, J., R. Virkkala and H. Toivonen 2009. Climate change and freshwater biodiversity: detected patterns, future trends and adaptations in northern regions. Biological Review 84: 3954. DOI: 10.1111/j.1469-185X.2008.00060.x.

Holt, R.E. and C. Jorgensen 2015. Climate change in fish: Effects of respiratory constraints on optimal life history and behavior. Biology Letters 11: 20141032

Howerton, R. 2001. Best management practises for Hawaiian aquaculture. CTSA 148: 7-31.

Hrubec, T.C., J.L. Cardinale and S.A. Smith 2000. Haematology and plasma chemistry reference intervals for cultured tilapia (Oreochromis hybrid). Veterinary Clinic Pathology 29: 7-12.

Idowu, E.O. and E.B. Afolayan 2013. The effects of supplementing of fish meal with maggots at varying levels in the diet of Claris gariepinus. International Archive of Applied Sciences and Technology 4(4): 41-47.

Kausar, R. and M. Salim 2006. Effect of water temperature on the growth performance and feed conversion ratio of Labeo rohita. Pakistan Veterinary Journal 26(3): 105-108.

Koeypudsa, W. and M. Jongjareanjai 2010. Effect of water temperature on hematology and virulence of Aeromonas hydrophila in hybrid catfish (Clarias gariepinus $\mathrm{x}$ C. macrocephalus). Thailand Journal Veterinary Medicine 40(2): 179-186.

Magawata, I. and J.K. Ipinjolu 2014. Climate change: Mitigation and adaptation strategies in fisheries and aquaculture in Nigeria. Journal of Aquatic Science 9(4): 257-261.

Mali, R.P. and P.N. Chavan 2014. Temperature dependent haematological alterations of 
freshwater cultivable fish, Oreochromis mossambicus from Nanded District (Ms) India. International Journal of Innovative Research in Science, Engineering and Technology 3(11): 17178-17180. DOI:10.15680/IJIRSET.2014.031 1013

Mugo-Bundi, J., E. Oyoo-Okoth, C.C. Ngugi, D. Manguya-Lusega, J.Rasowo and B.V.Chepkirui 2013. Utilization of Caridina nilotica (Roux) meal as a protein ingredient in feeds for Nile tilapia (Oreochromis niloticus). Aquaculture Resource 2: 1-12.

NAERLS 1996. National Agricultural Extension and Research Liaison Services. Water Quality Management in Fish Culture, Extension Bulletin No. 98, Fisheries Series No. 3.

NOAA Ocean Service Education 2008. Dissolved Oxygen.http://oceanservice.noaa.gov/educatio/ kits/estuaries/media/supp_estuar10d_disolvedo x.html

Ogunji, J.O., J. Nimpptsh, C. Wiegand and C. Schulz 2007. Evaluation of the influence of housefly maggot meal (Magmeal) diets on catalase, glutahione, S-transferase and glycogen concentration of the liver of Oreochromis niloticus fingerling. Comprehensive Biochemica Physioloy Part A. 20(147): 942-947.

Ogunji, J.O., R.S. Toor, C. Schulz and W. Kloas 2008. Growth performance, nutrients utilization of Nile Tilapia Oreochromis niloticus fed housefly maggot meal (Magmeal) diets. Turkish Journal of Fisheries and Aquatic Science 8: 141-147.

Okorafor, K.A. 2014. Ecological responses of freshwater components to climate change impacts: A review. ARPN Journal of Science and Technology 4(11): 654-665.

Oyawoye, E.O. and M. Ogunkunle 1998. Physiological and biochemical effects of raw
Jack beans on broilers. Proceedings of Annual Conference of Nigeria Society for Animal Production 23: 141-142.

Pörtner, H.O. and M.A. Peck 2010. Climate change effects on fishes and fisheries: towards a causeand-effect understanding. Journal of Fish Biology 77(8): 1745-79. DOI: $10.1111 / \mathrm{j} .1095-$ 8649.2010.02783.x.

Ramesh, M., R. Srinivasan and M. Saravanan 2009. Effect of atrazine (Herbicide) on blood parameters of common carp Cyprinus carpio (Actinopterygii:Cypriniformes).African Journal of Environmental Science and Technology 3(12): 453-458.

Schulz, C., U. Knaus, M. Wirth and B. Rennert 2005. Effects of varying dietary fatty acid profile on growth performance, fatty acid, body and tissue composition of juvenile pike perch (Sander lucioperca) Aquaculture Nutrition 11: 1-11.

Singh, S.P., T.A. Sharma and R. Chakrabarti 2013. Effects of water temperature on the physiological responses of Asian Catfish Clarias betrachus (Linnaeus 1758). Asian Fisheries Science 26: 26-38.

Sowunmi, A.A. 2003. Haematology of the African catfish, Clarias gariepinus (Burchell 1822) from Eleyele reservoir, Ibadan, Southwest Nigeria. The Zoologist 2(1): 40-44.

Tanck, M.W.T., G.H.R. Booms, E.H. Eding, S.E.W. Bonga and J. Komen 2000. Cold shocks: stressor for common carp. Journal Fish Biology 57: 881-894.

Wilson, R.W. and E.W. Taylor 1993. The physiological responses of freshwater rainbow trout, Onchorynchus mykiss, during acute exposure. Journal of Comparative Physiology 163b: 3847. 